\title{
INFLUENCE OF DIFFERENT CHEMICAL AGENTS AND STORAGE CONDITIONS ON THE MICROBIOLOGICAL CONTENT OF INDUSTRIAL HEMP (CANNABIS SATIVA L.) SEEDS
}

\author{
Nataša R. Đerić ${ }^{* 1}$, Olja M. Todorić ${ }^{1}$, Milana Đ. Rošul ${ }^{1}$, Sunčica D. Kocić-Tanackov ${ }^{2}$, Vladimir Š. Sikora ${ }^{3}$ \\ Biljana M. Kiprovski ${ }^{3}$, Anamarija I. Mandić ${ }^{1}$ \\ ${ }^{1}$ University of Novi Sad, Institute of Food Technology, 21000 Novi Sad, Bulevar cara Lazara 1, Serbia \\ ${ }^{2}$ University of Novi Sad, Faculty of Technology, 21000 Novi Sad, Bulevar cara Lazara 1, Serbia \\ ${ }^{3}$ Institute of Field and Vegetable Crops, 21000 Novi Sad, Maksima Gorkog 30, Serbia
}

\begin{abstract}
This study aimed to test different chemical agents to obtain microbiologically safe industrial hemp seeds that could be used for further food processing (with the reduced total number of microorganisms, total number of moulds and yeasts, and total number of Enterobacteriaceae). In order to obtain seeds applicable for food consumption, optimal storage temperature conditions (room temperature, refrigerator, freezer), method of seed packaging (vacuum/without vacuum), and the application of various chemical treatments (ethanol, sodium hydrogen carbonate, sodium hypochlorite) were tested on the certified industrial hemp seeds, produced in two consecutive years. Optimal storage conditions differed for different microorganisms, and the most optimal storage was at room temperature, for seeds produced in 2018 , in the treatment to reduce the total number of Enterobacteriaceae and the total number of microorganisms. When storing seeds from 2018 in order to reduce the number of yeasts and moulds, a slightly lower number was spotted when seeds were stored in a vacuum-sealed bag, at the refrigerator/freezer temperature. For hemp seeds produced in 2019, the most optimal storage conditions were at the refrigerator (for reduction of the total number of Enterobacteriaceae) and freezer temperature (for reduction of the total number of microorganisms). For the reduction of the total number of moulds and yeasts, optimal conditions were at room temperature. Ethanol $(75 \%, \mathrm{v} / \mathrm{v})$ was the most effective disinfectant among the tested chemicals regardless of the initial number of microorganisms, with log reduction of 3.2 (for the total number of Enterobacteriaceae), $2.9 \mathrm{log}$ (for the total number of microorganisms), and total reduction of the total number of yeasts and moulds after 10 minutes, for the seeds harvested in 2019, which were far more contaminated than the seeds harvested in 2018. Considering the price of the disinfection method with ethanol, sodium hypochlorite may be a better solution for the reduction of the number of microbiota on the seeds.
\end{abstract}

Key words: Cannabis sativa, disinfection, the total number of microorganisms, Enterobacteriaceae, moulds, yeasts

\section{INTRODUCTION}

Cannabis sativa L., industrial or fibre hemp is an annual, naturally dioecious plant from the Cannabinaceae family. Industrial hemp is produced for seed (oil and protein source), fibre, and flower. Its inflorescences are highly regarded from a medicinal point of view, due to the presence of phytocannabinoids, terpenoids, and phenylpropanoids. According to Small \& Beckstead (1973), a presence of (-)trans- $\Delta^{9}$-tetrahydrocannabinol (THC), the compound responsible for the psychoactive effects, and cannabidiol (CBD) in a low ratio, 
total THC/total CBD $(<1.0)$, positions industrial hemp as a fibre type (chemotype III). Industrial hemp contains less than $0.3 \%$ of THC on a dry weight basis, which is the legal limit in Serbia for industrial hemp production for fibre and seed, according to the Serbian national Rulebook (Pravilnik, 2013), while in Europe this limit is slightly lower $-0.2 \%$ (Frassinetti et al., 2020).

Industrial hemp seed is a nutritionally valuable source of proteins and oil since it contains all essential amino acids and fatty acids in sufficient amount for daily nutritional needs. The nutritional composition of hemp seed is $10-15 \%$ of insoluble fibres, $20-30 \%$ of carbohydrates, $20-25 \%$ of proteins, and $25-35 \%$ of lipids (Callaway, 2004). Hempseed oil contains up to $80 \%$ of polyunsaturated fatty acids, out of which the highest amount belongs to linoleic acid (omega-6) and alpha-linolenic acid (omega-3), with a ratio optimal for human health $(3: 1)$. Moreover, industrial hemp seed is a good source of highly digestible proteins, edestin and albumin, and free amino acids, among which the most important ones are arginine and glutamic acid (Callaway, 2004). Hemp oil contains antioxidants: $\alpha$-and $\gamma$-tocopherol, chlorophyll, phenolic acids, and flavonoids (Teh \& Birch, 2013).

Seeds, as well as the whole plant, are susceptible to different microbiological contaminations on the field, during storage, and in all involved processing stages. The contamination of seeds can occur from various sources: air, water, soil, animals, insects, and human factors. Due to the low activity of water and humidity on the surface of seeds, the growth of most microorganisms is prevented (Brar \& Danyluk, 2018). However, fungi/moulds are more resistant to adverse environmental conditions than other microorganisms, and therefore are more common microbiota on seeds. The penetration of fungi into the seeds can occur due to unfavourable environmental conditions, such as higher temperatures, precipitation, humidity, seed damage. By removing the testa (or seed coat), the number of microorganisms can be significantly reduced (Laca et al., 2006). Penicillium spp. (P. paxilli, $P$. citrinum, $P$. commune, $P$. chrysogenum, $P$. corylophilum, $P$. citrinum, and $P$. steckii), Aspergillus spp. (A. terreus, A. niger, A. flavus, A. versicolor, A. ostianus, and A. sydowii), and Fusarium sp. (F. oxysporum) (McPartland \&
Hillig, 2004; McKernan et al., 2016) are the most common fungal species on hemp seeds (Montoya et al., 2020). Bacterial species of Pseudomonas, Cellvibrio, Oxalobacteraceae, Xanthomonadaceae, Actinomycetales, and Sphingobacteriales (Winston et al., 2014), potential human pathogens, including Acinetobacter baumannii, Escherichia coli, Pseudomonas aeruginosa, Ralstonia pickettii, Salmonella enterica, Stenotrophomonas maltophilia, and Clostridium botulinum (McKernan et al., 2016) as well as Listeria sp. (McPartland \& McKernan, 2017) are the main source of contamination of hemp seeds (Montoya et al., 2020).

Seed coat structure and biochemical composition prevents mechanical damage and protect the seed from different pests. After harvesting, the most common sources of microbiological contamination are the human factor and unclean equipment (Yang et al., 2013). Microorganisms can survive and stay inactive under unfavourable conditions, but if there are any changes in temperature and/or moisture content in warehouse during storage, they are activated again (Žeželj, 1995). The contaminated seed is not suitable for direct use, neither as raw nor as a processed material (Plavšić et al., 2017).

In the food industry, sodium hypochlorite $(\mathrm{NaOCl})$ is the most commonly used disinfectant, due to its broad spectrum of action, rapid antibacterial action, but also due to the ease of application and low cost (Fukuzaki, 2006). The use of sodium hydrogen carbonate $\left(\mathrm{NaHCO}_{3}\right)$ in the food industry is more related to its sensory properties, although its antimicrobial power has been proven (Curran \& Montville, 1989; Afolabi \& Kareem, 2018; Kareem et al., 2018). The advantages of using sodium hydrogen carbonate as a disinfectant are its safety, simplicity of use, and low costs. Ethanol is a widely available disinfectant. Ethanol has strong antimicrobial properties, but due to its toxicity, the exposure time to this disinfecting agent should be as short as possible (Oyebanji et al., 2009).

This study aimed to test different chemical agents to obtain microbiologically safe industrial hemp seeds that could be used for further food processing. In order to obtain seeds applicable for food consumption, optimal temperature storage conditions (room temperature, refrigerator, freezer), method of 
seed packaging (vacuum/without vacuum), and the application of various chemical treatments (ethanol, sodium hydrogen carbonate, sodium hypochlorite) were investigated, aiming to reduce the number of microorganisms present on the hemp seed (the total number of microorganisms, the total number of moulds and yeasts, and the total number of Enterobacteriaceae).

\section{MATERIALS AND METHODS}

\section{Plant material}

Certified industrial hemp seeds (Cannabis sativa L.) cultivar 'Helena', harvested in 2018 and 2019, were provided by the Institute of Field and Vegetable Crops, Novi Sad, Serbia. Seeds were dried to approximately $9 \%$ moisture, for both harvest years. The weather conditions at a cultivation site during the development of the plants, as well as at the harvest time are presented in Figure 1.

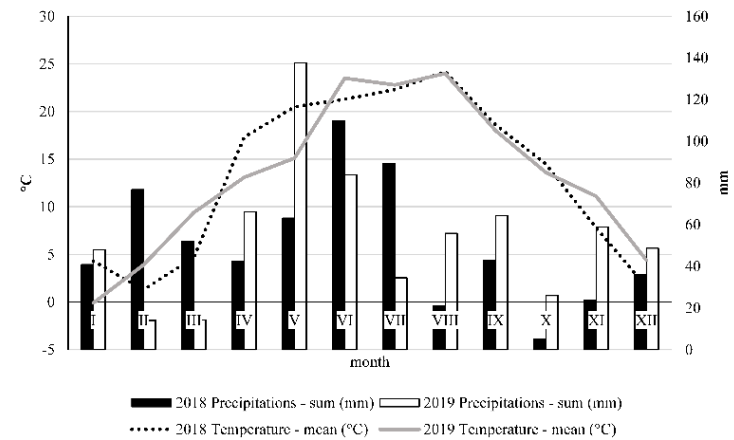

Figure 1. Weather conditions during hemp cultivation and harvest period

\section{Storage conditions}

Seeds (100 g) were placed in plastic bags and sealed under vacuum (Vacuum sealer VS 110 $\mathrm{W})$, or without vacuum. Each bag was stored at room temperature $\left(23{ }^{\circ} \mathrm{C}\right)$, at refrigerator temperature $\left(4^{\circ} \mathrm{C}\right)$, and freezer temperature ($20^{\circ} \mathrm{C}$ ), for 14 days before further testing.

Table 1.

Disinfection treatments of industrial hemp seeds

\begin{tabular}{|c|c|c|c|}
\hline $\begin{array}{l}\text { Industrial hemp seed } \\
\text { harvesting year }\end{array}$ & Disinfectant & $\begin{array}{l}\text { Time } \\
(\min )\end{array}$ & Concentration \\
\hline 2018 & Ethanol & $\begin{array}{l}2 \\
3 \\
4 \\
5\end{array}$ & $75(\%, v / v)$ \\
\hline 2019 & Ethanol & $\begin{array}{c}2 \\
5 \\
7 \\
10 \\
\end{array}$ & $75(\%, v / v)$ \\
\hline 2018 & $\begin{array}{l}\text { Sodium hydrogen carbonate } \\
\qquad\left(\mathrm{NaHCO}_{3}\right)\end{array}$ & $\begin{array}{c}1 \\
5 \\
15 \\
30\end{array}$ & $4(\%, w / v)$ \\
\hline 2019 & $\begin{array}{l}\text { Sodium hydrogen carbonate } \\
\qquad\left(\mathrm{NaHCO}_{3}\right)\end{array}$ & 30 & $\begin{array}{c}2(\%, \mathrm{w} / \mathrm{v}) \\
4(\%, \mathrm{w} / \mathrm{v}) \\
10(\%, \mathrm{w} / \mathrm{v}) \\
15(\%, \mathrm{w} / \mathrm{v})\end{array}$ \\
\hline 2018 & $\begin{array}{l}\text { Sodium hypochlorite } \\
\qquad(\mathrm{NaClO})\end{array}$ & $\begin{array}{c}5 \\
10 \\
15 \\
30\end{array}$ & $0.35(\%, \mathrm{v} / \mathrm{v})$ \\
\hline 2019 & $\begin{array}{l}\text { Sodium hypochlorite } \\
\qquad(\mathrm{NaClO})\end{array}$ & $\begin{array}{l}10 \\
15 \\
30 \\
35\end{array}$ & $0.35(\%, \mathrm{v} / \mathrm{v})$ \\
\hline
\end{tabular}




\section{Disinfection treatments of industrial hemp seeds}

Efficacy of ethanol $(75 \%, \mathrm{v} / \mathrm{v})$, sodium hydrogen carbonate $(2-15 \%, \mathrm{w} / \mathrm{v})$, and sodium hypochlorite $(0.35 \%, \mathrm{v} / \mathrm{v})$ as disinfectants for the bacteria, moulds and yeasts were tested on seeds, exposed to the disinfectants according to the time specified in Table 1. Seeds were stored at room temperature. Ten grams of seeds were selected and the experiment was done in three replicates. Distilled water was used for preparing the disinfectant solutions.

Each sample was immersed in a designated disinfectant solution of appropriate concentration, shaken using an Orbital Shaker (PSU-10i, BOECO Germany) for a defined period of time (presented in Table 1). Afterwards, the seeds were washed for 10 minutes and then transferred to sterile filter paper in a sterile chamber to allow the paper to absorb the remaining moisture.

The initial number of microorganisms on untreated seed was previously determined. Based on the obtained results, the concentrations of disinfection treatments and contact times were determined (shown in Table 1) in order to achieve a reduction in contamination for both types of seeds.

\section{Microbiological analysis}

Preparation of seed sample for microbiological testing, as well as preparation of initial suspension and decimal dilutions, was performed according to the method described in the standard SRPS EN ISO 6887-1:2017.

The total number of microorganisms was determined using the horizontal method, the colony counting technique at $30{ }^{\circ} \mathrm{C}$, according to the standard SRPS EN ISO 4833-1:2014. Using a sterile pipette, $1 \mathrm{~mL}$ of the initial suspension, as well as $1 \mathrm{~mL}$ of a 10-2 dilution was transferred to each Petri dish (inoculation was performed in duplicate). The procedure was repeated with the following decimal dilutions, if necessary. From $12 \mathrm{~mL}$ to $15 \mathrm{~mL}$ of Plate Count Agar (PCA) (Himedia, Mumbai, India) was poured into each Petri plate, carefully mixing the inoculum with the substrate. After solidification of the agar, the prepared plates were inverted and placed in an incubator at $30{ }^{\circ} \mathrm{C}$ for $72 \mathrm{~h}$. The results were obtained by the method of counting grown colonies on plates, and presented as the mean value of $\mathrm{CFU} / \mathrm{g}$.

The total number of Enterobacteriaceae was determined by the colony counting technique, according to the standard SRPS EN ISO 21528-2:2017. After preparation of the initial suspension, it was transferred to each Petri dish (and decimal dilutions, if necessary), in duplicate. Violet Red Bile Glucose (VRBG) agar (Himedia, Mumbai, India) was added to each plate $(15 \mathrm{~mL})$. After solidification of the agar, each plate was further covered with $5 \mathrm{~mL}$ to $10 \mathrm{~mL}$ of the same medium, and the plates were reversed to incubation at $37{ }^{\circ} \mathrm{C}$ for $24 \mathrm{~h}$. After that, the number of present characteristic purple-red colonies was read off. Such colonies suspected to be Enterobacteriaceae were subcultured on nutrient agar for further confirmation, and the plates were incubated at $37{ }^{\circ} \mathrm{C}$ for $24 \mathrm{~h}$. Biochemical tests such as the oxidase reaction and the glucose fermentation test confirmed that all the present characteristic colonies belonged to Enterobacteriaceae.

The total number of moulds and yeasts on hemp seed was determined by the colony counting technique on Dichloran 18\% Glycerol Agar (DG18) (Himedia, Mumbai, India), according to the standard SRPS ISO 215272:2011. The $\mathrm{pH}$ value of our DG18 was $\mathrm{pH} 5.6$ \pm 0.2 . Petri dishes with hemp seeds were incubated at $25{ }^{\circ} \mathrm{C}$. The results were obtained after 5 and 7 days.

The results present the mean value of three repetitions.

\section{RESULTS AND DISCUSSION}

\section{Microbiology test results of stored hemp seeds}

From the analysis of the initially present total number of microorganisms on the hemp seed, difference in the results can be observed between the seeds collected from 2018 and 2019 harvest (Table 2). It is important to highlight that neither hemp seeds from 2018 nor those from 2019 had visible signs of infection with moulds. The seeds from 2019 harvest were far more contaminated according to all parameters: total number of microorganisms, moulds and yeasts, and Enterobacteriaceae. The assumption for this difference is exposure to heavy rainfall and high moisture during the harvest period in 2019 (Figure 1). 
Exposure to high moisture during the seed development and harvest could support the accumulation of microorganisms, due to which drying process is essential in the prevention of postharvest spoilage (Bradford et al., 2018). In order to reduce contamination of hemp seed with microbiota, optimal storage conditions differed for different microorganisms. The optimal storage condition was at room temperature, for seeds originating from 2018 , regarding the reduction of the total number of Enterobacteriaceae and the total number of microorganisms. During storage of seeds originnating from 2018, a slightly lower number was spotted when samples were stored in a vacuum-sealed bag, at the refrigerator/freezer temperature considering the total number of seeds. For hemp seeds originating from 2019, the optimal storage conditions were at the refrigerator temperature (for reduction of the total number of Enterobacteriaceae) and the freezer temperature (for the total number of microorganisms). For the reduction of the total number of moulds and yeasts, optimal conditions were at room temperature.

By analysing the results obtained for the total number of microorganisms, an increasing trend of the total number of microorganisms present in the vacuum packaged seeds was recorded. An exception was observed for the lot of seeds harvested in 2018 and stored at freezer temperature, where there was a decrease of $0.2 \log$ unit (for the total number of Enterobacteriaceae), $0.3 \log$ (for the total number of microorganisms), and $0.4 \log$ (for the total number of moulds and yeasts), compared to the number of microbiota obtained for the lot stored without vacuum. At the re-frigerator temperature, a difference of $0.8 \mathrm{log}$ units by vacuum storage was also observed, compared to non-vacuum storage, for the total number of moulds and yeasts. An exception of the increasing trend in the number of microbiota on the seeds stored in a vacuum (lot harvested in 2019), was observed during storage at refrigerator temperature - a decrease of $0.2 \mathrm{log}$ unit (total number of microorganisms) and freezer temperature (total number of moulds and yeasts), compared to storage without vacuum. From the obtained results, it can be concluded that facultative anaerobic microorganisms predominated in the samples.
Considering the structure of hemp seed, it can be concluded that it is extremely suitable for the development of microbiological contamination. Numerous channels and cracks in the seed can be the main reason for the contamination. During washing the seeds, water does not reach them, which prevents removal of the dust, microorganisms, and their spores from the inside channels and cracks in the seed. The controlled conditions of storage, together with the procedures for hemp seed preparation before the treatment, could significantly lower contamination level. Mamun (2018) stated that temperature, moisture content and equilibrium relative humidity (ERH) are the most important parameters during hemp storage. Moulds are the main contaminants of hemp seeds, although bacteria and viruses are present, too. If the storage temperature is kept below $10{ }^{\circ} \mathrm{C}$, the growth of most storage moulds (except Penicillium) will be prevented (Singh, Paroha, \& Mishra, 2017; Mamun, 2018). Indicators of storage quality, according to Mamun (2018) are germination, fatty acid value, visible or invisible moulds, and seed plate (bacteria) count. According to Mamun (2018) moulds, regardless of relative humidity, were visible at all temperatures, so a storage temperature below $25{ }^{\circ} \mathrm{C}$ was recommended.

\section{Influence of chemical agents on the re- duction of the number of microorganisms}

The effect of disinfectant treatments on the presence of microorganisms was determined in the samples of hemp seeds harvested in two consecutive years (2018 and 2019) and depicted in Fig. 2.

Prolonged exposure to every tested disinfectant was found to partly eliminate contaminating microbiota from the seed surface, as it was expected. The seeds harvested in 2019 showed high contamination rates after exposure to ethanol at $2 \mathrm{~min}$, but minor contamination remained after 5-10 min treatment, after 14 days storage. In this experiment, ethanol $(75 \%, v / v)$ was the most effective disinfection treatment, with log reduction of 3.2 $\log$ (for the total number of Enterobacteriaceae), $2.9 \log$ (for the total number of microorganisms), and total reduction of the total number of moulds and yeasts after 10 minutes. 
Table 2.

Microbiological image of stored hemp seeds under different conditions for 14 days

\begin{tabular}{lccc}
\hline Sample & $\begin{array}{c}\text { Total number of } \\
\text { Enterobacteriaceae } \\
\text { (CFU/g) }\end{array}$ & $\begin{array}{c}\text { Total number of } \\
\text { microorganisms } \\
\text { (CFU/g) }\end{array}$ & $\begin{array}{c}\text { Total number of moulds } \\
\text { and yeasts } \\
\text { (CFU/g) }\end{array}$ \\
\hline RT18 & $7200 \pm 141.42$ & $20000 \pm 282.84$ & $5000 \pm 141.42$ \\
VRT18 & $12000 \pm 1272.8$ & $29000 \pm 565.69$ & $5000 \pm 0.0$ \\
RF18 & $20000 \pm 1697.1$ & $40000 \pm 707.11$ & $13000 \pm 707.11$ \\
VRF18 & $90400 \pm 2828.4$ & $120000 \pm 16970$ & $2000 \pm 282.84$ \\
F18 & $16000 \pm 424.26$ & $52000 \pm 2828.4$ & $5000 \pm 565.69$ \\
VF18 & $10500 \pm 141.42$ & $25000 \pm 989.95$ & $2000 \pm 141.42$ \\
\hline RT19 & $175200 \pm 1131.4$ & $254000 \pm 1414.2$ & $3000 \pm 424.26$ \\
VRT19 & $204000 \pm 8485.3$ & $300000 \pm 8485.3$ & $8000 \pm 141.42$ \\
RF19 & $71200 \pm 3394.1$ & $246000 \pm 4242.6$ & $8000 \pm 565.69$ \\
VRF19 & $124000 \pm 2828.4$ & $160000 \pm 5656.9$ & $8000 \pm 282.84$ \\
F19 & $76000 \pm 7071.1$ & $145000 \pm 1414.2$ & $6000 \pm 843.53$ \\
VF19 & $140000 \pm 1414.2$ & $192000 \pm 2828.4$ & $5000 \pm 707.11$ \\
\hline
\end{tabular}

$R T$ - Room temperature; VRT - Vacuum packed seed at room temperature; $R F$ - Refrigerator; VRF-Vacuum packed seed in the refrigerator; F- Freezer; VF - Vacuum packed in freezer, 18 - Hemp seed harvested in 2018; 19 - Hemp seed harvested in 2019; Results are presented as mean value \pm standard deviation.

Sodium hypochlorite $(0.35 \%$, v/v) had a slightly lower reduction rate for $35 \mathrm{~min}$ treatment: $\log$ reduction of 2.7 (for the total number of Enterobacteriaceae), 3.1 (for the total number of microorganisms), and total reduction of the total number of moulds and yeasts. Sodium hydrogen carbonate showed lowest reduction rates: $1.2 \log$ (for the total number of Enterobacteriaceae), $1.4 \mathrm{log}$ (for the total number of microorganisms), and 1.2 $\log$ (for the total number of moulds and yeasts) after 30 min of treatment with $15 \%(w / v)$ sodium hydrogen carbonate. Considering the price of the disinfection method with ethanol, sodium hypochlorite may be a better solution for the reduction of the microbial count on the seeds.

For hemp seeds originating from year 2018, all treatments showed satisfactory results, which is expected considering the initial number of microorganisms on the seeds. All tested disinfectants resulted in total reduction of the Enterobacteriaceae number: sodium hydrogen carbonate $(4 \%, \mathrm{w} / \mathrm{v})$ after 15 minutes, ethanol $(75 \%, v / v)$ after 5 minutes, and sodium hypochlorite $(0.35 \%, \mathrm{v} / \mathrm{v})$ after 10 minutes. Ethanol treatment for 5 minutes showed the best reduction $(2 \mathrm{log})$ for the total number of microorganisms, compared to all tested disinfectants. Both ethanol (2 min) and sodium hypochlorite $(15 \mathrm{~min})$ had shown the total reduction of the number of moulds and yeasts, while sodium hydrogen carbonate had a lower reduction rate (0.8 log after $30 \mathrm{~min})$.

Further studies with the treatment at several concentrations and times might be needed to identify the conditions that allow the total elimination of microorganisms. Each type of seed requires optimization of the disinfecting agent as well as the length of exposure to the agent.

So far no research has been conducted on the topic of disinfection treatments of hemp seeds. Oyebanjiet al. (2009) suggested that the use of locally produced bleach, containing $3.5 \%$ hypochlorite for $30 \mathrm{~min}$ is an effective sterilization method for cowpea, rice and sorghum seeds. Al-Amodi (2016) performed a research on the effect of hypochlorite for mouldy seed disinfection and came out with conclusion that the best reduction of moulds with hypochlorite (concentration of $1.5 \%, \mathrm{v} / \mathrm{v}$ ) was at 6 minutes. Aliyu (2018) had investigated the effects of sodium hypochlorite and ethanol at different concentrations on cowpea seeds. These chemicals were tested as sterilises of the Cowpea Mottle Virus, and ethanol had shown the best reduction results.

Sodium hydrogen carbonate and leaf extracts of Carica papaya showed good inhibiting power against Aspergillus niger and Botryodiplodia theobromae in soybean seeds (Afolabi \& Kareem, 2018). Effectiveness of 
sodium hydrogen carbonate was the object of another study conducted by Kareem et al. (2018). Sodium hydrogen carbonate had broad-spectrum activities on tested fungal species (Aspergillus niger, Candida spp., Rhizopus stolonifer, Pythium spp., Trichoderma spp.) and is therefore a good alternative to fungicides. The presented results are in accordance with the reports of other authors on disinfection treatments. Differences in the mycological results of certain types of seeds and hemp seeds can be due to differences in seed structure.
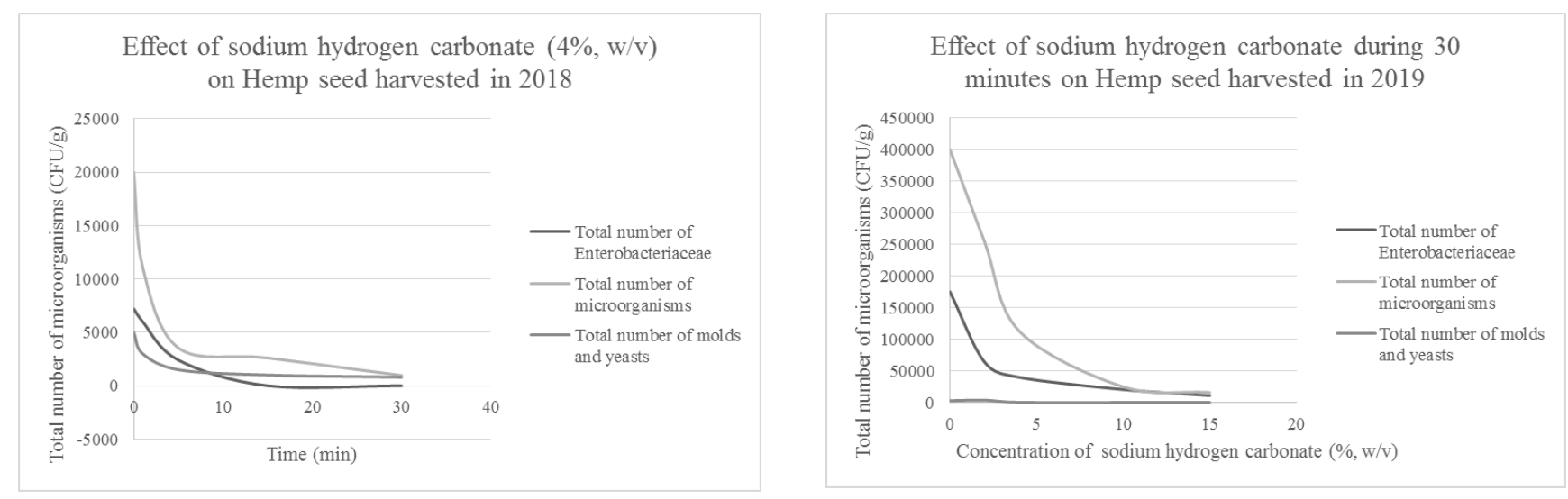

Effect of Ethanol $(75 \%, \mathrm{v} / \mathrm{v})$

on Hemp seed harvested in 2018

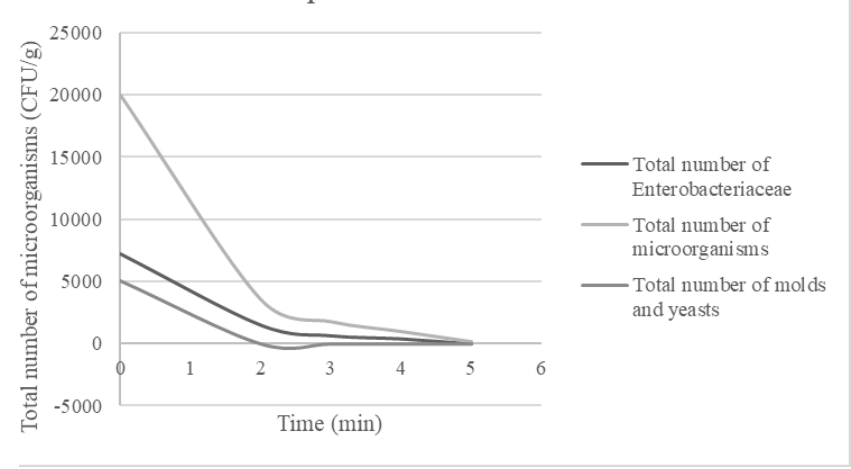

Effect of Ethanol $(75 \%, v / v)$

on Hemp seed harvested in 2019

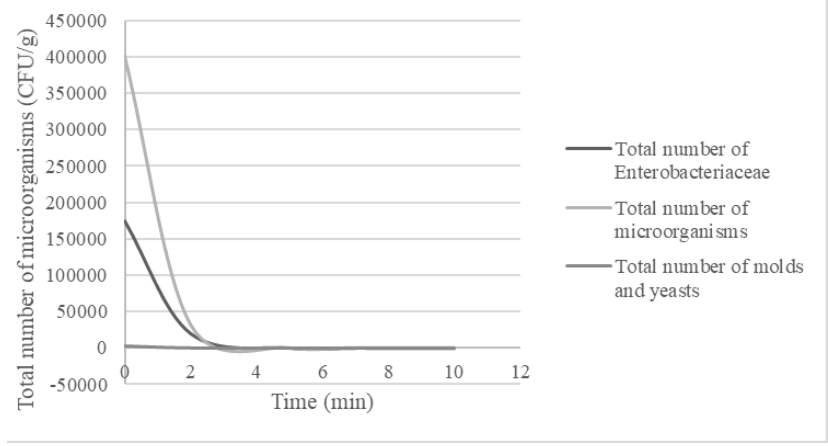

Effect of Sodium Hypochlorite $(0.35 \%$, v/v)

on Hemp seed harvested in 2018

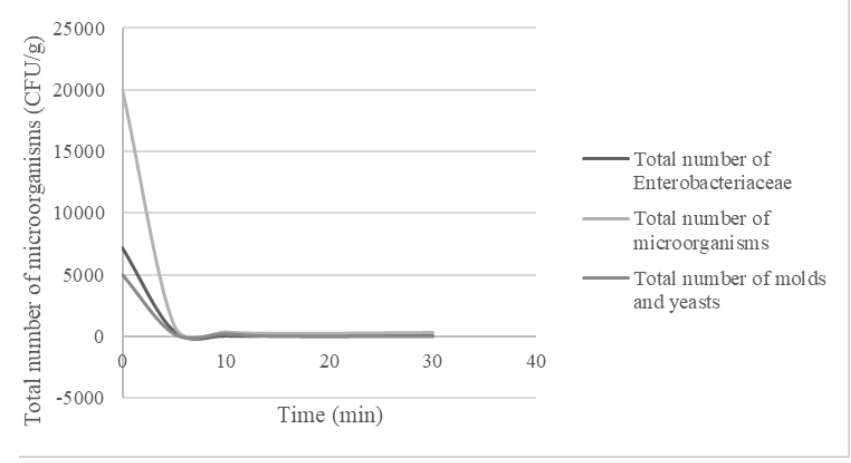

Effect of Sodium Hypochlorite $(0.35 \%$, v/v)

on Hemp seed harvested in 2019

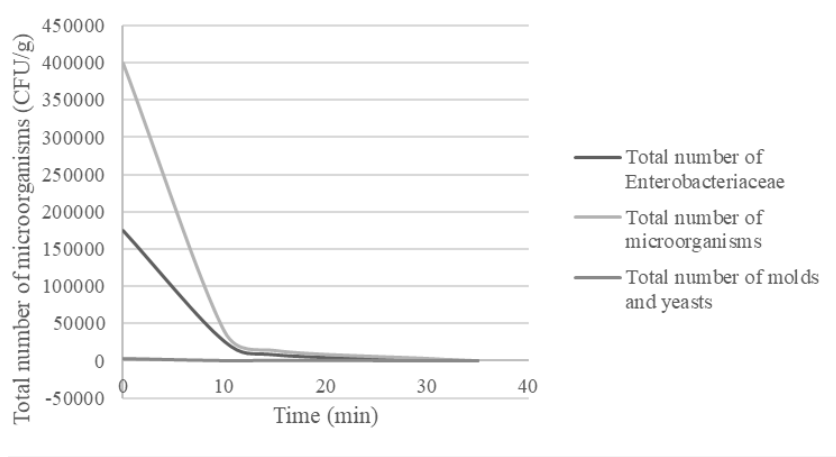

Figure 2. Effects of chemical treatments on microbial count on hemp seeds harvested in 2018 and 2019 


\section{CONCLUSIONS}

Hemp could be the food of the future, so it is very important to determine the optimal storage conditions, in order to prevent an increase in the initially present number of microorganisms on the seed. It is also important to determine the optimal seed disinfection treatments in order to ensure a microbiologically safe food product. Based on the obtained results, it can be concluded that hemp seeds should be stored at room temperature, without vacuum. Chemical treatments of hemp seeds can be efficiently used for lowering the total number of microorganisms, including the total number of Enterobacteriaceae, moulds and yeasts. Among tested disinfectants (ethanol, sodium hydrogen carbonate, sodium hypochlorite), ethanol was the most efficient one, but considering the cost of these chemicals sodium hypochlorite can be recommended. The overall efficiency of the treatments and selection of optimal concentration of disinfection agent as well as disinfection time very much depends on the initial load of microorganisms which should be determined prior to the treatments. Further research is needed for providing the most efficient and economically viable chemical disinfectant for hemp seeds but the potential use of new technologies such as cold plasma treatments is particularly interesting especially from the standpoint of avoiding the use of chemicals.

\section{ACKNOWLEDGEMENTS}

This research is funded by the Ministry of Education, Science and Technological Development of the Republic of Serbia (Contract No: 451-03-68/2020-14/200222; 451-03-68/2020-14/200032).

\section{REFERENCES}

Afolabi, Q. O., \& Kareem, K. T. (2018). Antifungal activities of Carica papaya and sodium bicarbonate against soybean fungi. International Journal of Biological and Chemical Sciences, 12(5), 20852092. https://doi.org/10.4314/ijbcs.v12i5.10

Al-Amodi, M. O. (2016). Fungi associated with seeds of Ashford variety of groundnut grown in Yemen and its disinfection in vitro using sodium hypochlorite. Journal of Global Biosciences, 5(1), 34143422.

Aliyu, T. H. (2018). The effect of Sodium Hypochlorite and Ethanol as seed sterilants on cowpea infected with Cowpea Mottle Virus. The Nigerian Journal of Pure and Applied Sciences, 31(1), 3122-3127.
Bradford, K. J., Dahal, P., Van Asbrouck, J., Kunusoth, K., Bello, P., Thompson, J., \& Wu, F., (2018). The dry chain: Reducing postharvest losses and improving food safety in humid climates. Trends in Food Science \& Technology, 71, 84-93. https://doi.org/10.1016/j.tifs.2017.11.002

Brar, P. K., \& Danyluk, M. D. (2018). Nuts and grains: microbiology and preharvest contamination risks. Microbiology Spectrum, 6(2). doi:10.1128/microbiolspec.pfs-0023-2018

Callaway, J. C. (2004). Hempseed as a nutritional resource: an overview. Euphytica, 140 (1-2), 65-72. https://doi.org/10.1007/s10681-004-4811-6

Curran, D. M., \& Montville, T. J. (1989). Bicarbonate inhibition of Saccharomyces cerevisiae and Hansenula wingei growth in apple juice. International Journal of Food Microbiology, 8(1), 1-9. https://doi.org/10.1016/0168-1605(89)90074-3

Frassinetti, S., Gabriele, M., Moccia, E., Longo, V., \& Di Gioia, D. (2020). Antimicrobial and antibiofilm activity of Cannabis sativa L. seeds extract against Staphylococcus aureus and growth effects on probiotic Lactobacillus spp. LWT, 124, 109149. https://doi.org/10.1016/j.lwt.2020.109149

Fukuzaki, S. (2006). Mechanisms of actions of sodium hypochlorite in cleaning and disinfection processes. Biocontrol Science, 11(4), 147-157. https://doi.org/10.4265/bio.11.147

Kareem, K. T., Afolabi, Q. O., Shorinmade, A. Y., \& Akinbode, O. A. (2018). Management of seedborne fungi in cowpea using leaf extracts and sodium bicarbonate. Journal of Applied Sciences and Environmental Management, 22(4), 565-570. https://doi.org/10.4314/jasem.v22i4.23

Laca, A., Mousia, Z., Díaz, M., Webb, C., \& Pandiella, S. S. (2006). Distribution of microbial contamination within cereal grains. Journal of Food Engineering, 72(4), 332-338. https://doi.org/10.1016/j.jfoodeng.2004.12.012

Mamun, M. Al. A. (2018). Safe storage guidelines for industrial hemp (Cannabis sativa) seeds (MSc thesis). University of Manitoba, Winnipeg, Canada.

McKernan, K., Spangler, J., Helbert, Y., Lynch, R. C., Devitt-Lee, A., Zhang, L., Orphe, W., Warner, J., Foss, T., Hudalla, C. J., \& Silva, M. (2016). Metagenomic analysis of medicinal Cannabis samples; pathogenic bacteria, toxigenic fungi, and beneficial microbes grow in culture-based yeast and mold tests. F1000Research, 5, 2471. https://doi.org/10.12688/f1000research.9662.1

McPartland, J. M., \& Hillig, K. W. (2004). Cannabis clinic Fusarium Wilt. Journal of Industrial Hemp, 9(2), 67-77.

McPartland, J. M., \& McKernan, K. J. (2017). Contaminants of concern in cannabis: microbes, heavy metals and pesticides. In S. Chandra, H. Lata, \& M. ElSohly (Eds.), Cannabis sativa L.-Botany and Biotechnology (pp. 457-474). Springer, Cham. https://doi.org/10.1007/978-3-319-54564-6_22

Montoya, Z., Conroy, M., Vanden Heuvel, B. D., Pauli, C. S., \& Park, S. H. (2020). Cannabis contaminants limit pharmacological use of cannabidiol. Frontiers in Pharmacology, 11, 1439. https://doi.org/10.3389/fphar.2020.571832

Pravilnik. (2013). Pravilnik o uslovima za gajenje konoplje. Službeni glasnik RS, 64/2013 
Oyebanji, O. B., Nweke, O., Odebunmi, O., Galadima, N. B., Idris, M. S., Nnodi, U. N., Afolabi, A.S., \& Ogbadu, G. H. (2009). Simple, effective and economical explant-surface sterilization protocol for cowpea, rice and sorghum seeds. African Journal of Biotechnology, 8(20), 5395-5399.

Plavšić, D. V., Škrinjar, M. M., Psodorov, Đ. B., Šarić, L. Ć., Psodorov, D. Đ., Varga, A. O. \& Mandić, A. I. (2017).Mycopopulations of grain and flour of wheat, corn and buckwheat. Food and Feed Research, 44(1), 39-45. https://doi.org/10.5937/FFR1701039P

Singh, J., Paroha, S., \& Mishra, R. P. (2017). Factors affecting oilseed quality during storage with special reference to soybean (Glycine max) and Niger (Guizotia abyssinica) seeds. International Journal of Current Microbiology and Applied Sciences, 6(10), 2215-2226. https://doi.org/10.20546/ijcmas.2017.610.262

Small, E., \& Beckstead, H. D. (1973). Common cannabinoid phenotypes in 350 stocks of Cannabis. Lloydia, 36(2), 144-165.

SRPS ISO. 21527-2:2011 (2011). Horizontal method for the enumeration of yeasts and moulds: Colony count technique in products with water activity less than or equal to 0.95 . Microbiology of food and animal feeding stuffs. Geneva, Switzerland: International Organization for Standardization.

SRPS EN ISO. 4833-1:2014 (2014). Horizontal method for the enumeration of microorganisms - Part 1: Colony count at $30{ }^{\circ} \mathrm{C}$ by the pour plate technique. Microbiology of the food chain. Geneva, Switzerland: International Organization for Standardization.
SRPS EN ISO 21528-2:2017. (2017). Horizontal method for the detection and enumeration of Enterobacteriaceae - Part 2: Colony-count technique. Microbiology of the food chain. Geneva, Switzerland: International Organization for Standardization.

SRPS EN ISO 6887-1:2017. (2017). Preparation of test samples, initial suspension and decimal dilutions for microbiological examination - Part 1: General rules for the preparation of the initial suspension and decimal dilutions. Microbiology of the food chain. Geneva, Switzerland: International Organization for Standardization.

Teh, S. S., \& Birch, J. (2013). Physicochemical and quality characteristics of cold-pressed hemp, flax and canola seed oils. Journal of Food Composition and Analysis, 30(1), 26-31. https://doi.org/10.1016/j.jfca.2013.01.004

Winston, M. E., Hampton-Marcell, J., Zarraonaindia, I., Owens, S. M., Moreau, C. S., Gilbert, J. A., Hartsel, J.,Kennedy, S. J., \& Gibbons, S.M. (2014). Understanding cultivar-specificity and soil determinants of the cannabis microbiome. PLOS ONE 9(9), e107415. https://doi.org/10.1371/journal.pone.0107415

Yang, Y., Meier, F., Ann Lo, J., Yuan, W., Lee Pei Sze, V., Chung, H. J., \& Yuk, H. G. (2013). Overview of recent events in the microbiological safety of sprouts and new intervention technologies. Comprehensive Reviews in Food Science and Food Safety, 12(3), 265-280. https://doi.org/10.1111/1541-4337.12010

Žeželj, M. (1995). Tehnologija žita i brašna, Novi Sad: Tehnološki fakultet, Univerzitet u Novom Sadu. 


\title{
УТИЦАЈ РАЗЛИЧИТИХ ХЕМИЈСКИХ СРЕДСТАВА И УСЛОВА СКЛАДИШТЕЊА НА МИКРОБИОЛОШКИ ПРОФИЛ СЕМЕНА ИНДУСТРИЈСКЕ КОНОПЉЕ (CANNABIS SATIVA L.)
}

\author{
Наташа Р. Ђерић ${ }^{1 *}$, Оља М.Тодорић ${ }^{1}$, Милана Ђ. Рошул ${ }^{1}$, Сунчица Д. Коцић-Танацков $^{2}$, Владимир Ш. \\ Сикора $^{3}$, Биљана М. Кипровски ${ }^{3}$, Анамарија И. Мандић ${ }^{1}$ \\ ${ }^{1}$ Универзитет у Новом Саду, Институт за прехрамбене технологије, 21000 Нови Сад, Булевар цара Лазара 1, Србија
${ }^{2}$ Универзитет у Новом Саду, Технолошки факултет, 21000 Нови Сад, Булевар цара Лазара 1, Србија
${ }^{3}$ Институт за ратарство и повртарство, 21000 Нови Сад, Макисма Горког 30, Србија
}

Сажетак: Циљ овог истраживања био је испитивање различитих хемијских средстава за добијање микробиолошки безбедног семена индустријске конопље, које би се могло користити за даљу прераду у храну (са смањеним укупним бројем микроорганизама, укупним бројем квасаца и плесни, и укупним бројем ентеробактерија). Да би се добило семе применљиво за исхрану, оптимални температурни услови складиштења (собна температура, фрижидер, замрзивач), начин паковања семена (вакуум/без вакуума) и примена различитих хемијских третмана (етанол, натријум хидроген карбонат, натријум хипохлорит) су тестирани на сертификованом семену индустријске конопље, произведеном у две узастопне године. Оптимални услови складиштења су се разликовали за различите микроорганизме, а најоптималније складиштење је било на собној температури, за семе из 2018. године, а у циљу смањења броја ентеробактерија и укупног броја микроорганизама. При складиштењу семена из 2018. године у циљу смањења броја плесни и квасаца примећен је нешто мањи број датих микроорганизама када је семе чувано у вакуумски затвореној врећици, на температури фрижидера/замрзивача. За семе конопље из 2019. године најоптималнији услови складиштења су били на температури фрижидера (за редукцију броја ентеробактерија) и у замрзивачу (за редукцију укупног броја микроорганизама). За смањење укупног броја плесни и квасаца, оптимални услови су били на собној температури. Етанол $(75 \%, \mathrm{v} / \mathrm{v})$ je био најефикасније средство за дезинфекцију међу испитиваним хемијским средствима, без обзира на почетни број микроорганизама, са $\log$ смањењем од 3,2 (за укупан број ентеробактерија), 2,9 log (за укупан број микроорганизама) и укупним смањењем броја квасаца и плесни након 10 минута деловања, за семе произведено 2019. године, које је било много више контаминирано у односу на семе из 2018. године. Узимајући у обзир цену метода дезинфекције етанолом, натријум хипохлорит може бити боље решење за смањење броја микробиота на семену.

Кључне речи: Cannabis sativa, дезинфекција, укупан број микроорганизама, ентеробактерије, плесни, квасичи

Received: 28 October 2020/Received in revised form: 07 December 2020/Accepted: 10 December 2020

Available online: December 2020

This is an open-access article under the CC BY license (http://creativecommons.org/licenses/by/3.0). 